ABDI: Jurnal Pengabdian dan Pemberdayaan Masyarakat ISSN: 2656-369X (Print), 2684-8570 (Online)

Volume 2 No. 2, Desember 2020

http://abdi.ppj.unp.ac.id/index.php/abdi

Email: abdi@ppj.unp.ac.id

DOI: https://doi.org/10.24036/abdi.v2i2.49

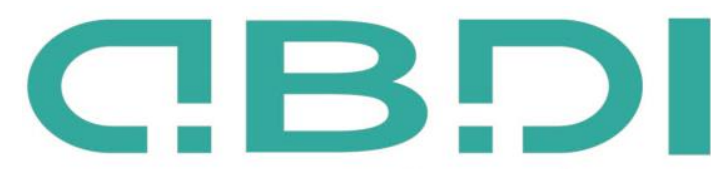

ABDI: JURNAL PENGABDIAN DAN PEMBERDAYAAN MASYARAKAT

\title{
Pemberdayaan Masyarakat Melalui Pengelolaan Sampah dalam Mengurangi Limbah Botol Plastik Kampung Nelayan Kelurahan Tanjung Ketapang
}

\author{
Apri Susanto ${ }^{1}$, Dedy Putranto ${ }^{2}$, Hengki Hartatadi ${ }^{3}$, Luswita $^{4}$, Maya Parina ${ }^{5}$, Rafi Fajri ${ }^{6}$, Sitiana \\ Sitiana $^{7}$, Septiara Septiara ${ }^{8}$, Yola Septian Amelinda ${ }^{9}$
}

STKIP Muhammadiyah Bangka Belitung

Email: septiaraa0@gmail.com

\begin{abstract}
Abstrak
Sampah menjadi masalah terbesar warga Nelayan, karena masyarakat yang masih berpikir dengan pola lama bahwa pantai atau sungai adalah tempat pembuangan sampah, dan sampah harus dibakar sepenuhnya, mengakibatkan tidak adanya pengelolaan sampah dan membuat lingkungan tercemar. Salah satu hal yang harus dilakukan untuk menanggulangi permasalahan ini adalah dengan mengelolah sampah tersebut agar menjadi barang yang bernilai Estetika yaitu dengan membuat sebuah kerajinan tangan berupa bunga menggunakan limbah botol plastik. Melakukan pelatihan kepada ibu-ibu dan anak-anak tentang cara pembuatan kerajinan tangan berupa bunga yang diletakkan didaerah pesisir pantai tepatnya pada tiang ayunan yang merupakan salah satu program yang kami lakukan. Pengelolaan Limbah Botol Plastik ini diharapkan mampu memberdayakan masyarakat dan memberi kesadaran bagi masyarakat agar lebih peduli dengan sampah. Pemberdayaan Masyarakat adalah upaya yang dilakukan untuk meningkatkan kesadaran masyarakat tentang sampah dan Menanamkan nilai-nilai budaya modern seperti kerja keras, hemat, keterbukaan, tanggung jawab adalah bagian penting dalam upaya pemberdayaan.
\end{abstract}

Kata Kunci: Pengelolaan Limbah Botol Plastik, Pemberdayaan Masyarakat, Simulasi

\section{Abstract}

Garbage is the biggest problem for fishermen, because people who still think with the old pattern that the beach or river is a garbage dump, and garbage must be burned completely, resulting in the absence of waste management and polluting the environment. One of the things that must be done to overcome this problem is to treat the waste to become an Aesthetic valuable item by making a handicraft in the form of flowers using plastic bottle waste. Conduct training for mothers and children on how to make handicrafts in the form of flowers placed in the coastal areas, precisely on the swing pole, which is one of our programs. Plastic Bottle Waste Management is expected to be able to empower the community and provide awareness for the community to be more concerned with waste. Community Empowerment is an effort made to increase public awareness about waste and to instill modern crocodile values such as hard work, saving, openness, responsibility is an important part of empowerment efforts.

Keywords: Community Empowerment, Plastic Bottle Waste Management, Simulation

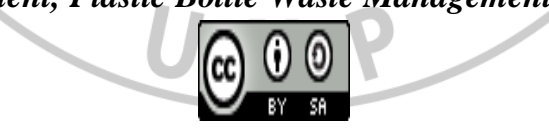

Received: 3 Maret 2020 


\section{Pendahuluan}

Penggunaan plastik di Indonesia tidak dibatasi. Plastik banyak digunakan untuk kebutuhan alat rumah tangga dan produksi, khususnya untuk kemasan makanan dan minuman. Sisa kemasan tersebut banyak dibuang begitu saja yang menyebabkan penumpukan limbah plastik semakin meningkat. Setiap pabrik menghasilkan rata-rata satu ton limbah plastik setiap minggunya. Jumlah tersebut akan terus bertambah, karena sifat dari pelastik antara lain tidak dapat membusuk, tidak terurai secara alami, tidak dapat menyerap air, maupun tidak dapat berkarat, dan pada akhirnya menjadi masalah bagi lingkungan. Limbah botol plastik masih dianggap sebagai sampah yang kurang bermanfaat. Padahal limbah botol plastik dapat dimanfaatkan menjadi beraneka ragam bentuk barang yang berguna yang dapat mempercantik ruang atau si pemakainya. Khususnya, pemanfaatan limbah botol air mineral bukanlah sekedar mencari keuntungan material saja melainkan sebagai bagian menjaga kelestarian lingkungan.

Sampah adalah sisa kegiatan sehari-hari manusia dan dari proses alam yang berbentuk padat. Sampah terbagi menjadi dua, yaitu sampah organik dan sampah non organik. Sampah organik adalah sisa buangan yang berasal dari makhluk hidup baik manusia, hewan maupun tumbuhan dan sifatnya yang mudah membusuk. Bakteri merupakan agen yang sangat penting keberadaannya karena perannya sebagai pengurai alami, sampah ini sangat ramah lingkungan karena memang berasal dari makhluk hidup sehingga jika kita berhadapan dengan sampăh organik tidak perlu bahan kimia, karena nantinya dia akan terurai sendiri. Sedangkan sampah non organik adalah segala sisa manusia yang sulit diurai kembali oleh bakteri atau memerlukan waktu yang cukup lama untuk penguraiannya hingga ratusan tahun. Sampah ini dihasilkan dari berbagai macam proses dan tidak akan bisa terurai oleh bakteri secara alami. Laju produksi sampah terus meningkat, tidak saja sejajar dengan laju pertumbuhan penduduk tetapi juga sejalan dengan meningkatnya pola konsumsi masyarakat. Di sisi lain kapasitas penanganan sampah yang dilakukan masyarakat maupun pemerintah daerah belum optimal. Sampah yang tidak dikelola dengan baik akan berpengaruh terhadap lingkungan dan kesehatan masyarakat sekitarnya. Komposisi sampah yang dihasilkan dari aktivitas manusia adalah sampah organik sebanyak $60-70 \%$ dan sisanya adalah sampah non organik $30-40 \%$, sementara itu dari sampah non organik tersebut komposisi sampah terbanyak kedua yaitu sebesar 14\% adalah sampah plastik. Sampah plastik yang terbanyak adalah jenis kantong plastik atau kantong kresek selain plastik kemasan.

Sumber sampah menurut Gilbert, dkk. 1996 (Aminudin \& Nurwati 2019), yaitu:

a. Permukiman penduduk

Pada permukiman penduduk, sampah dihasilkan oleh beberapa keluarga yang tinggal di suatu bangunan atau asrama.Jenis sampah yang dihasilkan biasanya cenderung sampah organik, seperti sisa makanan atau jenis sampah lainnya yang dapat bersifat basah, kering, abu plastik, dan lainnya.Sampah dari permukiman penduduk disebut juga sampah rumah tangga.

b. Tempat umum dan perdagangan

Tempat umum adalah tempat yang dimungkinkan banyaknya orang berkumpul dan melakukan kegiatan.Tempat tersebut mempunyai potensi cukup besar dalam memproduksi sampah, termasuk tempat perdagangan seperti pertokoan dan pasar. Jenis sampah yang dihasilkan umumnya berupa sisasisa makanan, sampah kering, abu, plastik, kertas, kaleng, dan jenis sampah lainnya.

c. Sarana pelayanan masyarakat milik pemerintah

Sarana pelayanan masyarakat milik pemerintah, misalnya tempat hiburan umum, pantai, masjid, rumah sakit, bioskop, perkantoran, dan sarana pemerintah lainnya yang menghasilkan sampah kering dan sampah basah.

d. Industri

Dalam pengertian ini termasuk pabrik-pabrik atau perusahaan dalam melakukan kegiatan industri yang menghasilkan sampah, baik yang termasuk distribusi ataupun proses suatu bahan mentah. Sampah yang dihasilkan dari industri biasanya berupa sampah basah, sampah kering, abu, dan sisa bahan bangunan.

e. Pertanian 
Sampah dihasilkan dari daerah pertanian, misalnya sampah dari kebun, kandang, ladang atau sawah yang berupa bahan makanan pupuk maupun bahan pembasmi serangga tanaman.

Sampah menjadi masalah terbesar warga Nelayan, karena masyarakat yang masih berpikir dengan pola lama bahwa pantai atau sungai adalah tempat pembuangan sampah, dan sampah harus dibakar sepenuhnya, mengakibatkan tidak adanya pengelolaan sampah dan membuat lingkungan tercemar. Pencemaran lingkungan yang semakin meningkat disebabkan oleh berbagai hal, seperti bertambahnya populasi manusia yang mengakibatkan meningkatnya jumlah sampah yang dibuang. Hal ini diperburuk dengan kurang memadainya tempat dan lokasi pembuangan sampah, kurangnya kesadaran dan kemauan masyarakat dalam mengelola dan membuang sampah, masih kurangnya pemahaman masyarakat tentang manfaat sampah, serta keengganan masyarakat memanfaatkan kembali sampah, karena sampah dianggap sebagai sesuatu yang kotor. Berbagai hal tersebut menyebabkan menurunnya kualitas lingkungan yang berdampak negatif bagi masyarakat.

Sampah sangat berbahaya bagi kesehatan manusia dan lingkungan sekitar. Oleh karena itu, sampah haruslah diolah dengan baik agar tidak mencemari lingkungan dan mengganggu kesehatan manusia. Sampah yang selama ini kita buang begitu saja, ternyata masih dapat diolah kembali antara lain dalam bentuk kerajinan tangan yang nantinya akan dijadikan hiasan, bercita rasa seni dan unik. Secara umum pengelolaan sampah dilakukan dalam tiga tahap kegiatan, yaitu : pengumpulan, pengangkutan, dan pembuangan akhir/pengolahan. Pada tahap pembuangan akhir/pengolahan, sampah akan mengalami proses-proses tertentu, baik secara fisik, kimiawi, maupun biologis.

Dalam hal ini masalah yang sedang terjadi di Kampung Nelayan yaitu berkaitan dengan sistem pengelolaan sampah. Masih terdapat sampah rumah tangga yang berserakan di lingkungan Kampung Nelayan. Sampah yang bêrasal dari rumah tangga merupakan konstribusi yang paling besar untuk timbulan sampah, disamping itu sampah rumah tangga merupakan sampah yang berbahaya karena dikategorikan sebagai sampah B3 (Bahan Beracun Berbahaya). Kemudian masalah sampah yang menumpuk di tempat sampah yang ada di setiap depan rumah warga Kampung Nelayan, sampahnya hanya diangkut dan diambil oleh petugas kebersihan satu minggu sekali yaitu pada hari Kamis. Oleh karena itu, banyak sampah rumah tangga yang berserakan melebihi kapasitas bak sampah yang sudah disediakan. Apabila dibiarkan sampah tersebut akan menimbulkan bau yang tidak sedap. Hal ini berdampak terhadap menurunnya kualitas lingkungan yang disebabkan oleh sampah yang tidak dikelola dengan baik dan ramah lingkungan.

Menurut Sumodiningrat (1999), bahwa pemberdayaan masyarakat merupakan upaya untuk memandirikan masyarakat lewat perwujudan potensi kemampuan yang mereka miliki. Masyarakat memiliki peran penting dalam kegiatan tersebut, disamping sebagai penghasil sampah tiap harinya masyarakat juga terlibat langsung dalam kegiatan tersebut. Melalui pendekatan pemberdayaan masyarakat diharapkan dapat meningkatkan kesadaran masyarakat serta meningkatkan ketrampilan dan kemandirian masyarakat sehingga kegiatan tersebut dapat berjalan dengan baik dan berkelanjutan. Keterlibatan masyarakat dapat dimulai dari perubahan perilaku dalam pemakaian barang-barang yang berpotensi menjadi sampah dapat dikurangi (reduce), memanfaatkan sampah yang masih layak dipakai (reuse) dan mendaur ulang sampah menjadi produk baru (recycle). Sampah merupakan masalah yang rumit yang secara terus menerus akan dihadapi oleh manusia, karena jika tidak ditangani dengan baik akan menimbulkan masalah yang merugikan manusia sendiri (Prasetya, 2010).

Tetapi dalam pelaksanaan kegiatan pemberdayaan masyarakat dalam pengelolaan sampah dalam mengurangi limbah botol plastik masih menimbulkan beberapa permasalahan dalam pengelolaan sampah diantaranya masih terdapatnya sampah-sampah di TPS dan tong sampah yang seharusnya dapat dimanfaatkan kembali oleh masyarakat seperti botol minuman, kaleng dll. Masih tercampurnya antara sampah organik dan anorganik di bak pemilahan dan bak pengangkutan sampah. Tercampurnya sampah tersebut akan menghambat proses pengolahan sampah karena masyarakat harus memilah sampah terlebih dahulu sebelum mengolah sampah sehingga waktu yang dibutuhkan untuk mengolah sampah lebih lama. Apabila hal ini dibiarkan akan menjadi sarang nyamuk yang nantinya dapat menimbulkan 
penyakit bagi masyarakat. Oleh sebab itu perlu adanya pengelolaan sampah dalam mengurangi limbah botol plastik dengan baik tanpa menimbulkan dampak yang buruk terhadap lingkungan.

Dilihat dari beberapa permasalahan diatas maka permasalahan utama yang muncul yaitu masyarakat yang masih belum terlibat dan mampu dalam kegiatan pemberdayaan pengelolaan sampah dalam mengurangi limbah botol plastik. Untuk itu, yang menjadi pertanyaan Pengabdian Masyarakat ini ialah "Bagaimana Pemberdayaan Masyarakat Melalui Pengelolaan Sampah Dalam Mengurangi Limbah Botol Plastik Kampung Nelayan Kelurahan Tanjung Ketapang".

Adapun tujuan dari pengabdian masyarakat ini yaitu mengkaji pemberdayaan masyarakat melalui pengelolaan sampah dalam mengurangi limbah botol plastik Kampung Nelayan Kelurahan Tanjung Ketapang.

Manfaat dari pengabdian masyarakat ini untuk masa yang akan datang yaitu untuk memberikan gambaran tentang pemberdayaan masyarakat dalam pengelolaan sampah, memberi masukan bagi pemerintah sebagai salah satu alternatif dalam menghadapi permasalahan persampahan di Kampung Nelayan dan memberi gambaran tentang pengelolaan sampah masyarakat yang juga dapat mengurangi limbah botol plastik karena mengurangi sampah langsung dari sumbernya.

Pengelolaan sampah bertujuan untuk meningkatkan kesehatan masyarakat dan kualitas lingkungan serta menjadikan sampah sebagai sumberdaya. Dari sudut pandang kesehatan lingkungan, pengelolaan sampah dipandang baik jika sampah tersebut tidak menjadi media berkembangbiaknya bibit penyakit serta sampah tersebut tidak menjadi medium perantara menyebarluasnya suatu penyakit. Syarat lainnya yang harus dipenuhi, yaitu tidak mencemari udara, air dan tanah, tidak menimbulkan bau (tidak mengganggu nilai estetis), tidak menimbulkan kebakaran dan yang lainnya.

\section{Metode Pelaksanaan}

Permasalahan yang diangkat dalam memberdayakan masyarakat melalui pengelolaan Limbah botol plastik yaitu diharapkan mampu memberikan keasadaran bagi masyarakat terkuhusnya Kampung Nelayan agar dapat mengurangi populasi sampah yang berserakan di sekitar Kampung Nelayan.

Tahap pengumpulan data yang kami lakukan untuk melaksanakan hal tersebut yaitu dengan berbagai cara, diantaranya:

1. Melakukan observasi awal di Kampung Nelayan selama tiga hari pada tanggal 8 Januari -10 Januari 2020.

2. Melakukan pengajaran kepada ibu-ibu maupun anak-anak untuk berlatih membuat sebuah kerajinan dari botol plastik.

3. Proses pengumpulan data yang kami lakukan adalah wawancara langsung ketua RT dan Masyarakat setempat.

Sasaran kegiatan ini adalah masyarakat Kampung Nelayan dimulai dari anak-anak hingga dewasa. Mereka mempunyai keinginan untuk berpartisipasi dalam membuat program yang kami rencanakan.

Kegiatan ini merupakan kegiatan yang menghasilkan suatu produk maka metode yang digunakan adalah Pertama, 30\% teori berupa ceramah, disertai contoh-contoh dan diskusi kelompok. Kedua, $70 \%$ berupa demo dan praktek langsung barang produksi (bunga). 


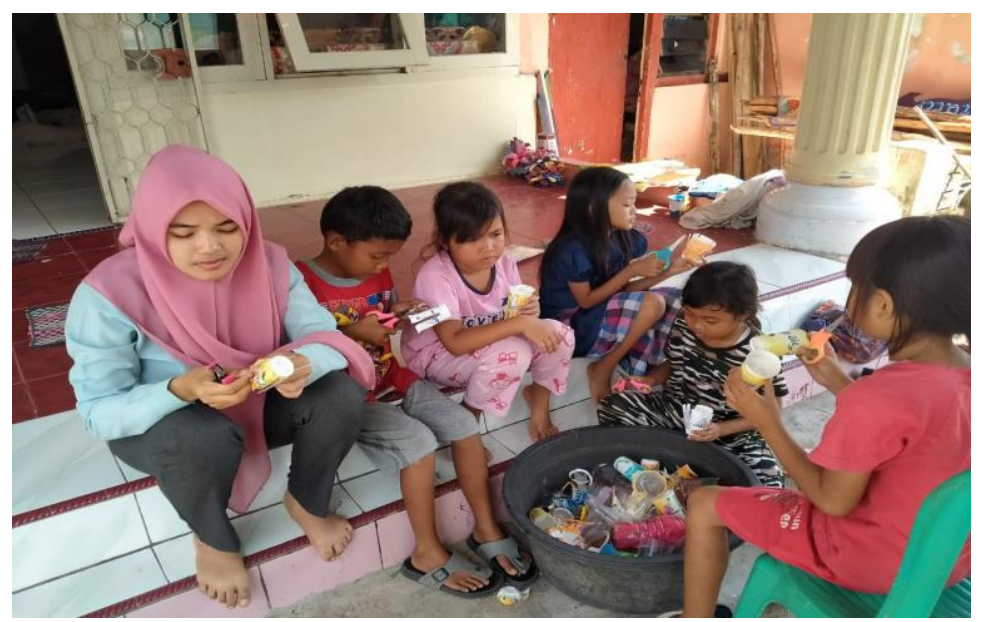

\section{Gambar 1. Pelatihan pembuatan kerajinan tangan dari Limbah Plastik}

\section{Hasil dan Pembahasan}

Berdasarkan observasi awal pertama-tama melihat lingkungan sekitar yang ada di sekitar pantai nelayan. Pantai di Kampung Nelayan sangat jarang dikunjungi oleh masyarakat sekitar, serta pantai tersebut kurang terawat. Sehingga banyak sampah yang dibuang secara di sengaja maupun kiriman dari selokan yang berakhir menuju pantai tersebut. Limbah sampah dari pasar Kampung Suka Damai juga menjadi masalah bagi masyarakat Kampung Nelayan. Oleh karena itu, sampah di pantai nelayan pun semakin bertambah banyak dan berserakan di pesisir pantai. Hal ini lah yang membuat pengabdi mengambil tindakan untuk mengelola sampah dalam mengurangi resiko limbah botol plastik yang berada di pantai tersebut.

Pengabdi mengambil tindakan dengan cara mengumpulkan botol-botol bekas. Kemudian botolbotol tersebut diolah menjadi bunga hias untuk dijadikan spot foto agar pantai lebih indah dan asri. Sehingga penulis melakukan perbaikan lingkungan pantai kampung Nelayan ini menjadi pantai yang layak untuk dikunjungi agar dapat dikenal oleh masyarakat Toboali dan sekitarnya untuk menikmati suasana pantai yang indah dan asri untuk menarik pengunjung. di lihat dari jumlah pengunjung sebelum dilakukan perbaikan pantai tersebut kurang diminati dan setelah dilakukan perbaikan pantai ini lebih banyak yang mengunjungi tetapi, yang banyak mengunjunginya adalah anak-anak. hal ini dibuktikan dengan lampiran foto pengunjung yang dilakukan selama proses KKN 28 hari. harapan program ini dibuat agar Pantai Nelayan tersebut dikenali oleh masyarakat toboali dan sekitarnya melalui perbaikan lingkungan pantai yang telah kami lakukan, sehingga program-program yang direncanakan dapat terrealisasi dengan baik dan dapat diselesaikan tepat waktu.

Pemberdayaan masyarakat adalah konsep pembanguan ekonomi yang merangkum nilai-nilai masyarakat untuk membangun paradigma baru dalam pembangunan yang bersifat people-centered, participatory, empowerment and sustainable. Lebih jauh Chamber menjelaskan bahwa konsep pembangunan dengan model pemberdayaan masyarakat tidak hanya semata-mata memenuhi kebutuhan dasar (basic need) masyarakat tetapi lebih sebagai upaya mencari alternative pertumbuhan ekonomi lokal.

Menurut Munawar Noor (2011 : 88-89) Pemberdayaan masyarakat (empowerment) sebagai model pembangunan berakar kerakyatan adalah upaya untuk meningkatkan harkat dan martabat sebagian masyarakat kita yang masih terperangkap pada kemiskinan dan keterbelakangan. Di tinjau dari sudut pandang penyelenggaraan Administrasi Negara, pemberdayaan masyarakat tidak sematamata sebuah konsep ekonomi tetapi secara implicit mengandung pengertian penegakan demokrasi ekonomi (yaitu kegiatan ekonomi berlangsung dari rakyat, oleh rakyat dan untuk rakyat). Dengan demkian konsep ekonomi yang dimaksud menyangkut penguasaan teknologi, pemilikan modal, akses pasar serta ketrampilan manajemen. Oleh karena itu agar demokrasi ekonomi dapat berjanan, maka 
aspirasi harus ditampung dan dirumuskan dengan jelas oleh birokrasi pemerintah dan tertuang dalam rumusan kebjakan public (public policies) untuk mencapai tujuan yang dikehendaki masyarakat.

\section{Pemanfaatan Sampah Anorganik}

Sampah anorganik adalah sampah yang berasal bukan dari makhluk hidup. Sampah anorganik memerlukan waktu yang lama atau bahkan tidak dapat terdegradasi secara alami. Beberapa sampah anorganik diantaranya styrofoam, plastik, kaleng, dan bahan gelas atau beling. Salah satu pemanfaatan sampah anorganik adalah dengan cara proses daur ulang (recycle). Daur ulang merupakan upaya untuk mengolah barang atau benda yang sudah tidak dipakai agar dapat dipakai kembali. Beberapa limbah anorganik yang dapat dimanfaatkan melalui proses daur ulang, misalnya plastik, gelas, logam, dan kertas.

\section{Sampah Plastik}

Sampah plastik biasanya digunakan sebagai pembungkus barang. Plastik juga digunakan sebagai perabotan rumah tangga seperti ember, piring, gelas, dan lain sebagainya. Keunggulan barang-barang yang terbuat dari plastik yaitu tidak berkarat dan tahan lama. Banyaknya pemanfaatan plastik berdampak pada banyaknya sampah plastik. Padahal untuk hancur secara alami jika dikubur dalam tanah memerlukan waktu yang sangat lama. Karena itu, upaya yang dapat dilakukan adalah memanfaatkan limbah plastik untuk didaur ulang menjadi barang yang sama fungsinya dengan fungsi semula maupun digunakan untuk fungsi yang berbeda. Misalnya ember plastik bekas dapat didaur ulang dan hasil daur ulangnya setelah dihancurkan dapat berupa ember kembali atau dibuat produk lain seperti sendok plastik, tempat sampah, atau pot bunga. Plastik dari bekas makanan ringan atau sabun deterjen dapat didaur ulang menjadi kerajinan misalnya kantong, dompet, tas laptop, tas belanja, sandal, atau payung. Botol bekas minuman bisa dimanfaatkan untuk hiasan bunga, vas bunga. Sedotan minuman dapat dibuat bunga - bungaan, asbak, pot, bingkai foto, taplak, hiasan dinding atau hiasan lainnya.

\section{Sampah Logam}

Sampah dari bahan logam seperti besi, kaleng, alumunium, timah, dan lain sebagainya dapat dengan mudah ditemukan di lingkungan sekitar kita. Sampah dari bahan kaleng biasanya yang paling banyak kita temukan dan yang paling mudah kita manfaatkan menjadi barang lain yang bermanfaat. Sampah dari bahan kaleng dapat dijadikan berbagai jenis barang kerajinan yang bermanfaat. Berbagai produk yang dapat dihasilkan dari limbah kaleng di antaranya tempat sampah, vas bunga, gantungan kunci, celengan, gif box dll.

\section{Sampah Gelas atau Kaca}

Sampah gelas atau kaca yang sudah pecah dapat didaur ulang menjadi barang barang sama seperti barang semula atau menjadi barang lainseperti botol yang baru, vas bunga, cindera mata, atau hiasanhiasan lainnya yang mempunyai nilai artistik dan ekonomis.

\section{Sampah Kertas}

Sampah dari kertas dapat didaur ulang baik secara langsung ataupun tak langsung. Secara langsung artinya kertas tersebut langsung dibuat kerajinan atau barang yang berguna lainnya. Sedangkan secara tak langsung artinya kertas tersebut dapat dilebur terlebih dahulu menjadi kertas bubur, kemudian dibuat berbagai kerajinan. Hasil daur ulang kertas banyak sekali ragamnya seperti kotak hiasan, sampul buku, bingkai photo, tempat pinsil, dan lain sebagainya.

Dari penjelasan diatas maka kita mengetahui bahwa sampah anorganik diperlukan waktu puluhan bahkan ratusan tahun untuk membuat sampah bekas kantong plastik itu benar-benar terurai. Namun yang menjadi persoalan adalah dampak negatif sampah plastik ternyata sebesar fungsinya juga, dibutuhkan waktu 1000 tahun agar plastik dapat terurai oleh tanah secara terdekomposisi atau terurai dengan sempurna. Ini adalah sebuah waktu yang sangat lama. Saat terurai, partikel-partikel plastik akan mencemari tanah dan air tanah.

Jika dibakar, sampah plastik akan menghasilkan asap beracun yang berbahaya bagi kesehatan yaitu jika proses pembakaranya tidak sempurna, plastik akan mengurai di udara sebagai dioksin. 
Senyawa ini sangat berbahaya bila terhirup manusia. Dampaknya antara lain memicu penyakit kanker, hepatitis, pembengkakan hati, gangguan sistem saraf dan memicu depresi. Untuk menangani permasalahan sampah ini secara menyeluruh maka diperlukan alternatif pengolahan yang benar. Teknologi landfill yang diharapkan dapat menyelesaikan masalah lingkungan akibat sampah, justru memberikan permasalahan lingkungan yang baru. Kerusakan tanah, air tanah, dan air permukaan sekitar akibat air lindi, sudah mencapai tahap yang membahayakan kesehatan masyarakat, khususnya dari segi sanitasi lingkungan.

\section{Pengelolaan Sampah dan 3R}

Pengelolaan sampah adalah semua kegiatan yang dilakukan untuk menangani sampah sejak ditimbulkan sampai dengan pembuangan akhir (Sejati, 2009), pengelolaan sampah meliputi tahapan:

a. Penimbulan sampah,

b. Penanganan di tempat,

c. Pengumpulan,

d. Pengangkutan,

e. Pengolahan, dan

f. Pembuangan akhir. lain:

Beberapa teknik yang digunakan dalam pengelolaan sampah menurut (Damanhuri, 2004) antara

a. Sampah diolah menjadi kompos

Sampah biologis, basah atau organik dapat dijadikan kompos dengan menimbun sampah tersebut di tanah dalam jangka waktu tertentu hingga membusuk.

b. Sampah digunakan sebagai makanan ternak

Sampah berupa buah-buahan dan sayur-sayuran yang belum sepenuhnya rusak dapat dijadikan makanan ternak atau binatang lain yang dikembangbiakkan. Umumnya sampah dari sayur dan buah dijumpai di pasar-pasar tradisional dan berserakan di mana-mana.

c. Metode landfill

Metode ini paling mudah karena hanya membuang dan menumpuk sampah di tanah yang rendah pada area terbuka.Metode ini menggangguestetika lingkungan.

d. Metode sanitary landfill

Metode ini mirip metode landfill, namun sampah yang ada ditutup dan diuruk dengan tanah.Metode ini biasanya menggunakan alat-alat berat berharga mahal seperti backhoeleskavator dan buldozer.

e. Metode pulverization Pulverisation

Adalah metode pembuangan sampah langsung ke laut lepas setelah dihancurkan menjadi potongan-potongan kecil.

f. Metode incineration/incinerator

Metode incineration adalah pembakaran sampah baik dengan cara sederhana maupun modern secara masal. Teknologi memungkinkan hasil energi pembakaran diubah menjadi energi listrik. Reduce (mengurangi), Reuse (pakai ulang), Recycle (daur ulang) (3R) adalah prinsip utama mengelola sampah mulai dari sumbernya, melalui berbagai langkah yang mampu mengurangi jumlah sampah yang dibuang ke tempat pembuangan akhir (ESP-USAID, 2010). Menurut Ni Komang Ayu Artiningsih (2008), tindakan yang dapat dilakukan pada setiap sumber sampah melalui 3R adalah:

a. Reduce (mengurangi), melalui tindakan:

1) Menghindari pemakaian dan pembelian produk yang menghasilkan sampah dalam jumlah besar.

2) Menggunakan produk yang dapat diisi ulang, misalnya penggunaan cairan pencuci dengan wadah isi ulang.

3) Mengurangi penggunaan bahan sekali pakai, misalnya penggunaan tisu yang diganti dengan sapu tangan atau serbet. 
b. Reuse (pakai ulang), melalui tindakan:

1) Menggunakan kembali wadah untuk fungsi yang sama atau fungsi lainnya, misalnya penggunaan kaleng dan botol bekas.

2) Menggunakan wadah yang dapat digunakan berulang-ulang, misalnya saat belanja membiasakan membawa tas belanja sendiri sehingga tidak memerlukan tas plastik lagi.

c. Recycle (daur ulang), melalui tindakan:

1) Memilih produk yang dapat didaur ulang dan mudah terurai.

2) Menggunakan sampah organik untuk dijadikan kompos dengan berbagai cara yang ada.

3) Menggunakan sampah anorganik untuk dijadikan aneka kreasi barang yang bermanfaat.

4) Pengelolaan Sampah Anorganik menjadi Aneka Kreasi Daur Ulang Dalam sistem atau model pengelolaan sampah berbasis masyarakat ditunjukkan bahwa sampah rumah tangga berupa sampah organik dapat dijadikan kompos, sedangkan sampah anorganik dapat didaur ulang, digunakan kembali, dan dimusnahkan (ESP-USAID, 2010). Daur ulang adalah proses memanfaatkan bahan bekas atau sampah untuk menghasilkan produk yang dapat digunakan kembali. Daur ulang memiliki manfaat, antara lain: (a) mengurangi jumlah sampah yang dibuang ke tempat pembuangan akhir, (b) mengurangi dampak lingkungan yang terjadi akibat menumpuknya sampah di lingkungan, (c) dapat menambah penghasilan melalui penjualan produk daur ulang yang dihasilkan, (d) mengurangi penggunaan bahan alam untuk kebutuhan industri plastik, kertas, logam, dan lain-lain.Kegiatan daur ulang sampah anorganik dapat dilakukan di tingkat rumah tangga ataupun komunal (RT, RW, desa). Di tingkat rumah tangga, sampah anorganik dapat dikelola dengan menyediakan ruangan di suatu pojok rumah yang tidak mengganggu kegiatan lainnya, namundiketahui dan mudah dicapai oleh semua anggota keluarga. Gunakan kardus, keranjang, ember bekas atau apa saja sebagai wadah masing-masing sampah anorganik (kertas, plastik, dan lain-lain) dan tempatkan wadah di tempat yang kering sampah anorganik tersebut kemudian dapat dijadikan aneka kreasi (hasta karya) daur ulang.

\section{Kesimpulan}

Hasil dan pembahasan yang telah kami bahas dapat diambil kesimpulan diantaranya: (1) Sampah adalah suatu bahan yang terbuang atau dibuang dari sumber hasil aktivitas manusia maupun proses alam yang belum memiliki nilai ekonomis yang dapat dibedakan menjadi sampah organik dan sampah anorganik. (2) Pemanfaatan sampah anorganik adalah dengan cara proses daur ulang (recycle). Beberapa limbah anorganik yang dapat dimanfaatkan melalui proses daur ulang, misalnya plastik, gelas, logam, dan kertas. (3) Pemanfaatan limbah botol plastik menjadi prakarya bunga yang dijadikan sebagai tempat untuk berfoto merupakan upaya menekan pencemaran limbah plastik di lingkungan Kampung Nelayan dan pendidikan lingkungan hidup.

\section{Daftar Pustaka}

Aminudin, A \& Nurwati, N. (2019). Pemanfaatan Sampah Plastik Menjadi Kerajinan Tangan Guna Meningkatkan Kreatifitas Warga Sekitar Institut Teknologi dan Bisnis Ahmad Dahlan (ITBAD) Jakarta. Jurnal Pengabdian Kepada Masyarakat, 2 (1), 66-79.

Ayu, A. (2008). Peran Serta Masyarakat Dalam Pengelolaan Sampah Rumah Tangga (Studi Kasus Di Sampangan Dan Jomblang, Kota Semarang). Tesis. Universitas Diponegoro Semarang.

Azwar, Azrul. (1986). Pengantar Ilmu kesehatan Lingkungan. Jakarta: Mutiara Sumber Widya.

Damanhuri, E., dkk., (2004). Diktat Pengelolaan Sampah.

Munawar, N. (2011). Pemberdayaan Masyarakat. Jurnal Ilmiah CIVIS, 1(2), 87-99

Nuraprilia, R. (2018). Pemberdayaan Masyarakat Melalui Pengelolaan Sampah Dalam Meningkatkan Kesehatan Lingkungan: Studi Deskriptif di Bank Sampah Wargi Manglayang, RW 06

Kelurahan Palasari, Kecamatan Cibiru, Kota Bandung. Disertasi. UIN Sunan Gunung Djati. 
Nurhidayah, P. (2017). Pemberdayaan Masyarakat Melalui Bank Sampah di Dusun Serut, Desa Palbapang, Kecamatan Bantul, Kabupaten Bantul. Jurnal Permberdayaan Masyarakat, 15(2), $1-10$.

Prasetya, A. (2010). Kajian Pemberdayaan Masyarakat Dalam Pengelolaan Sampah Secara Terpadu Di Kampung Menoreh Kota Semarang. Skripsi. Universitas Diponegoro Semarang, Semarang.

Shinta, D \& Vera, U. (2010). Pemanfaatan Limbah Botol Plastik Melalui Pelatihan Wirausaha Produk Aksesoris Bagi Ibu Rumah Tangga. Jurnal Sarwahita. 11(2), 99-108.

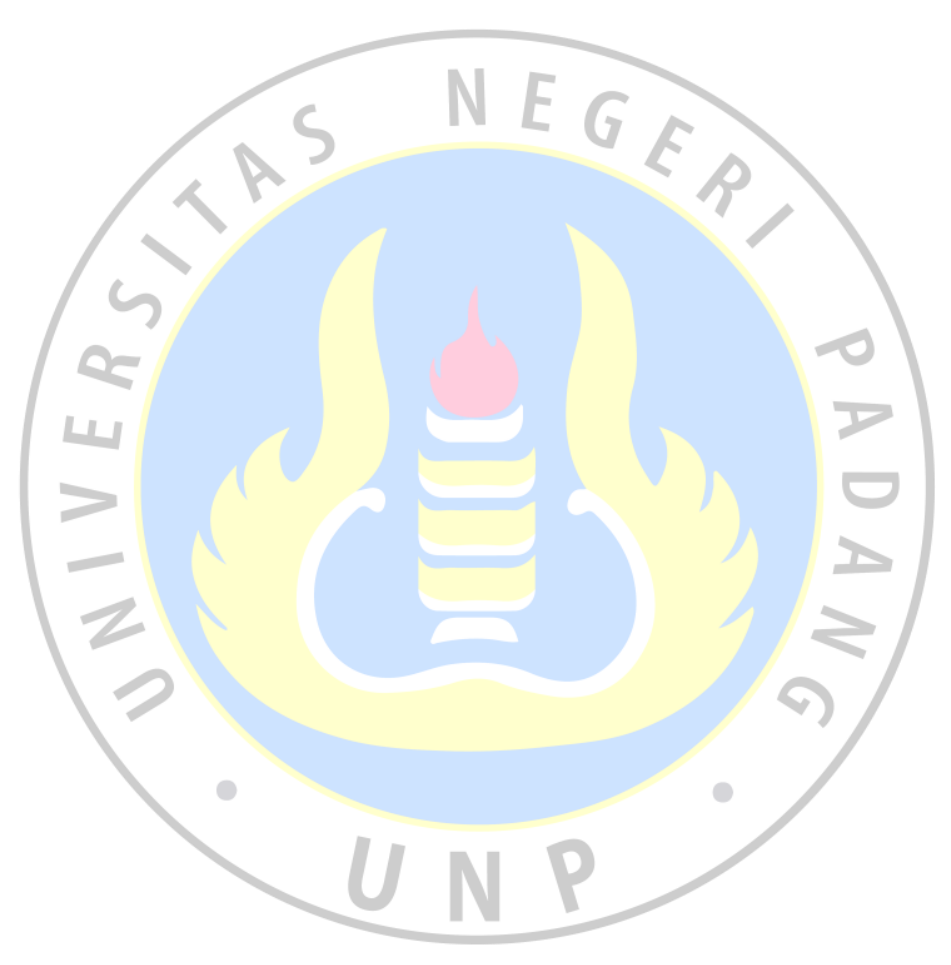

